\title{
Two new stygobiont freshwater snail species from Hungary (Mollusca: Gastropoda: Truncatelloidea)
}

\author{
ANDRÁs VARga \\ Mátra Museum of the Hungarian Natural History Museum, \\ H-3200 Gyöngyös, Kossuth Lajos utca 40, Hungary \\ E-mail:avarga8946@gmail.com
}

\begin{abstract}
Two new snail species are described, namely Paladilhiopsis pallgergelyi sp. n. from the valley of the River Dráva, and Alzoniella katagabriellae sp. n. from the Börzsöny Mountains. This is the first record of the genus Alzoniella Giusti \& Bodon, 1984 from Hungary. An interesting dwarf form of Bythinella austriaca (Fraunfeld, 1856) is also recorded from the Börzsöny Mountains.
\end{abstract}

Key words - Gastropoda, Moitessieriidae, Paladilhiopsis, Hydrobiidae, Alzoniella, Hungary

\section{INTRODUCTION}

Four stygobiont freshwater snail species have been reported so far from Hungary. Soós (1927) described Lartetia hungarica, whereas WAGNER (1931) introduced Lartetia gebhardti from the caves of Abaliget and Mánfa, respectively (both Mecsek Mountains, Southern Hungary, county Baranya). Based on conchological characters, the latter was considered a junior synonym of the former by PINTÉR (1968a). However, both morphometric and molecular genetic differences were found in a recent paper (ANGYAL et al. 2018), suggesting that they might be distinct species or subspecies. Both are treated as species and are currently classified in Paladilhiopsis Pavlović, 1913 (MolluscaBASe 2021). PIntér (1968b) described Paladilhia oshanovae from the debris of the river Danube from Esztergom, the current status is Bythiospeum oshanovae (FEHÉR et al. 2006). This species was later found alive in the Szigetköz Region in northwestern Hungary (MAjoros 2010). The fourth species, Hauffenia kissdalmae, was found in a spring in the Börzsöny Mts in northern Hungary ERöss \& PETró (2008).

I monitored the mollusc species in the Natura 2000 areas of the DanubeDrava National Park (DDNP) between 2008 and 2020. In 2018, I found shells of a hitherto unknown species of Moitesseriidae. I visited the very site multiple times during the following years, and I succeeded in finding additional shells. 
Similarly to my work for the Danube-Ipoly National Park (DINP) in 2002, I was assigned to conduct research on the Natura 2000 mollusc species. During this work, I found tiny shells of a hydrobiid species in the mud of a spring. Occurrence of unknown stygobiont species was surprising in both cases (Figs 1-2).

Classification of subterranean freshwater species is challenging based on conchological characters alone, because their shells have contain too few useful characters (Hershler \& PONDER 1998, Szarowska 2006; Falniowski 2018). However, in most cases it is very hard or even impossible to find living specimens for anatomical and molecular genetic analyses. In the present case, the shell shape and the sculpture of the protoconch and the teleoconch gave some support (FALNIOWSKI 1989, 1990, SZAROWSKA 2006, HOFMAN et al. 2018), and hence this provided enough ground to describe them as species new to science.

\section{MATERIALS AND METHODS}

Shell whorls were counted according to KERNEY \& CAMERON (1979). Scanning electron microscope images were made with Hitachi TM4000 Plus SEM by Barna Páll-Gergely.

Abbreviations for collections $-\mathrm{JG}=$ Private collections of Jozef Grego, Bańská Bystrica (Slovakia), HNHM = Hungarian Natural History Museum, Budapest (Hungary), VA = Private collections of András Varga, Gyöngyös (Hungary).

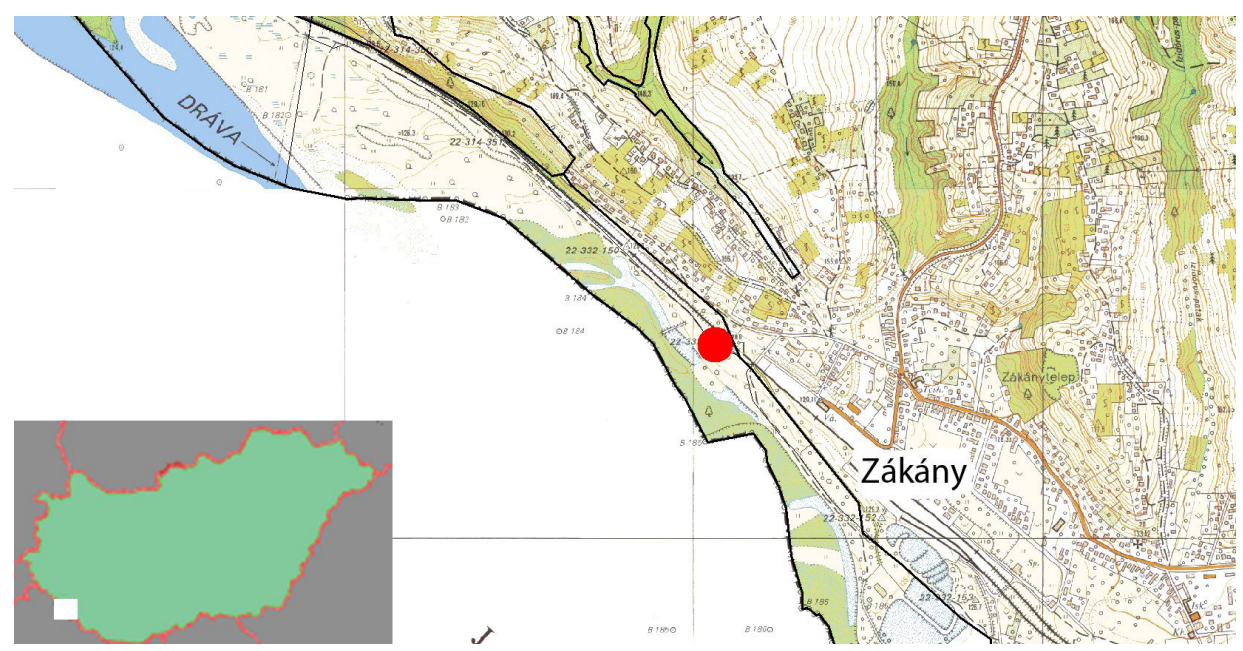

Figure 1. Geographical location of Paladilhiopsis pallgergelyi sp. n. locus typicus in the Drava River valley (County Somogy, Hungary) 


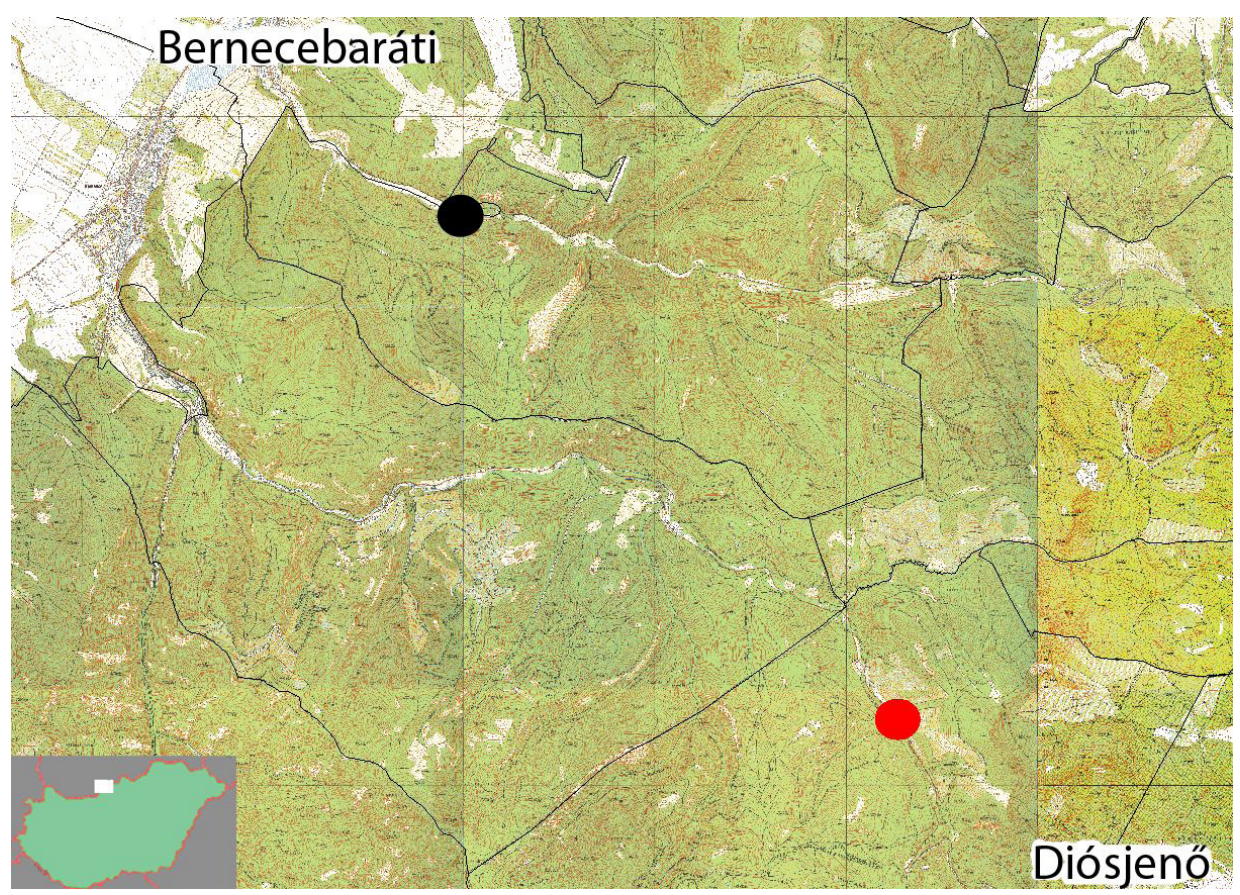

Figure 2. Geographical location of Alzoniella katagabriellae sp. n. locus typicus (red circle and occurrence of Bythinella austriaca (Frauenfeld, 1856) "dwarf form" (black circle) in Börzsöny Mountains (Counties Nógrád and Pest, Hungary)

\section{RESULTS}

Superfamily TRUNCATELLOIDEA J. E. Gray, 1840

Family MOITESSIERIIDAE Bourguignat, 1863

Genus Paladilhiopsis Pavlović, 1913

Type species: Paladilhia robiciana Clessin, 1882; SD (Wagner 1928: 291, 292). 


\section{Paladilhiopsis pallgergelyi sp. $\mathrm{n}$.}

(Figs 3-7, 10-11, 17-20, 21-22)

Type material - Holotype: Hungary, Somogy couny, southeast of Zákány, base of Látó-hegy [mountain], unnamed stream, 46 $15.378^{\prime} \mathrm{N}, 16^{\circ} 56.013^{\prime} \mathrm{E}$, $121 \mathrm{~m}$ a.s.l., leg. A. Varga 03.10.2019. (HNHM-MOL-100000). Paratypes $(n=4)$ : one shell, same data as for holotype, coll. JG; two shells, same data as for holotype, leg. A. Varga, 08.11.2018., coll. VA; one shell, same data as for holotype, leg. A. Varga, 08.11.2018., HNHM 105276.

Holotype measurements - Shell height: $2.14 \mathrm{~mm}$; shell width: $1.21 \mathrm{~mm}$; aperture height: $0.77 \mathrm{~mm}$; aperture width: $0.61 \mathrm{~mm}$.

Diagnosis - A Paladilhiopsis species with cylindrical shell, wide middle whorls and fine surface sculpture.

Description - Holotype: Shell elongate, nearly cylindrical; whorls 4.25, bulging, suture deep; aperture oval, leans slightly right from shell axis; aperture height larger than height of penultimate whorl from apertural view; peristome not expanded, sharp; umbilical area broad, and gradually becomes narrower (Fig. 10); protoconch sculpture with tiny pits (Figs 19-20); teleoconch sculpture overal extremely fine, with fine growth lines and dense spiral striate (Figs 17-18). Paratype (Fig. 11) slightly deformed, with higher spire, whorls 4.75; protoconch sculpture stronger than that of holotype, with conspicuous wrinkles (Figs 21-22).

Operculum and soft anatomy unknown.

Distribution - This new species is known only from the type locality, which is situated based on the geo-coordinates, the site is ca. $100 \mathrm{~m}$ far from (in the Hungarian side) the Croatian-Hungarian border (Figs. 3-7).

Etymology - The new species is named in honour of Barna Páll-Gergely, a dedicated malacologist and friend of the author.

Remarks on identification - Paladilhiopsis pallgergelyi sp.n. is clearly distinct from Paladilhiopsis species of Austria, Balkans and northern Italy based on the cylindrical shell, the wider middle and apical whorls, and the fewer number of whorls.

The species Paladilhiopsis grobbeni grobbeni Kuščer, 1928, P. grobbeni anzeiana (Slapnik, 1995), P. robiciana robiciana (Clessin, 1882), P. robiciana illustris (Schütt, 1970), P. robiciana kostanjevicae (Schütt, 1970), P. robiciana trebnikana (Slapnik, 1995), all possess shells that are conical, wide at their base, have large apertures and reticulated sculpture (CLESSIN 1882, SсHÜTt 1970, Radoman 1983, SLAPNIK 1995, Hofman et al. 2018).

The species of Paladilhiopsis from Croatia and Slovenia, P. absoloni (A. J. Wagner, 1914); P. insularis Cindrić \& Slapnik, 2019; P. pretneri (Bole \& Velkovrh, 1987), are more slender than the new species, and their apex is more pointed (Wagner 1914, Cindrić 2015, Cindrić \& SLAPNiK 2019). In contrast, the shell of $P$. pallgergelyi sp. n. is more cylindrical and its apex is blunt. 
The apex of Paladilhiopsis species from Bosnia and Herzegovina, P. blihensis (Glöer \& Grego, 2015), P. bosniaca (Clessin, 1910), P. maroskoi (Glöer \& Grego, 2015), P. solida (Kuščer, 1933), is more pointed and slender (KUščER 1933, SCHÜtT 1970; GlÖER \& GREgo 2015; HofmaN et al. 2018). The last whorl of $P$. brandisi (Clessin, 1911) is similar to that of the new species, but the apical part is wider, and the aperture is proportionally larger (WAGNER 1928). The aperture of $P$. serbica (Pavlović, 1913) is similar to that of the new species, but the apical whorls are more slender, not bulging (SснÜтT 1970).

The Paladilhiopsis species from Montenegro, Kosovo and Albania are all slender, in a few species the base of the shell is wide. Thus, those can be easily distinguished from $P$. pallgergelyi sp. n. (ReIschütz \& ReISCHÜtz 2008, GrEgo et al. 2017, 2019, HOFMAN et al. 2018).

The species Paladilhiopsis carpathica (Soós, 1940) from Transylvania and P. hungarica (Soós, 1927) from Hungary are more slender than P.pallgergelyi sp. n, and the formation of the aperture is also different (Soós 1927, RotARIDES 1943).

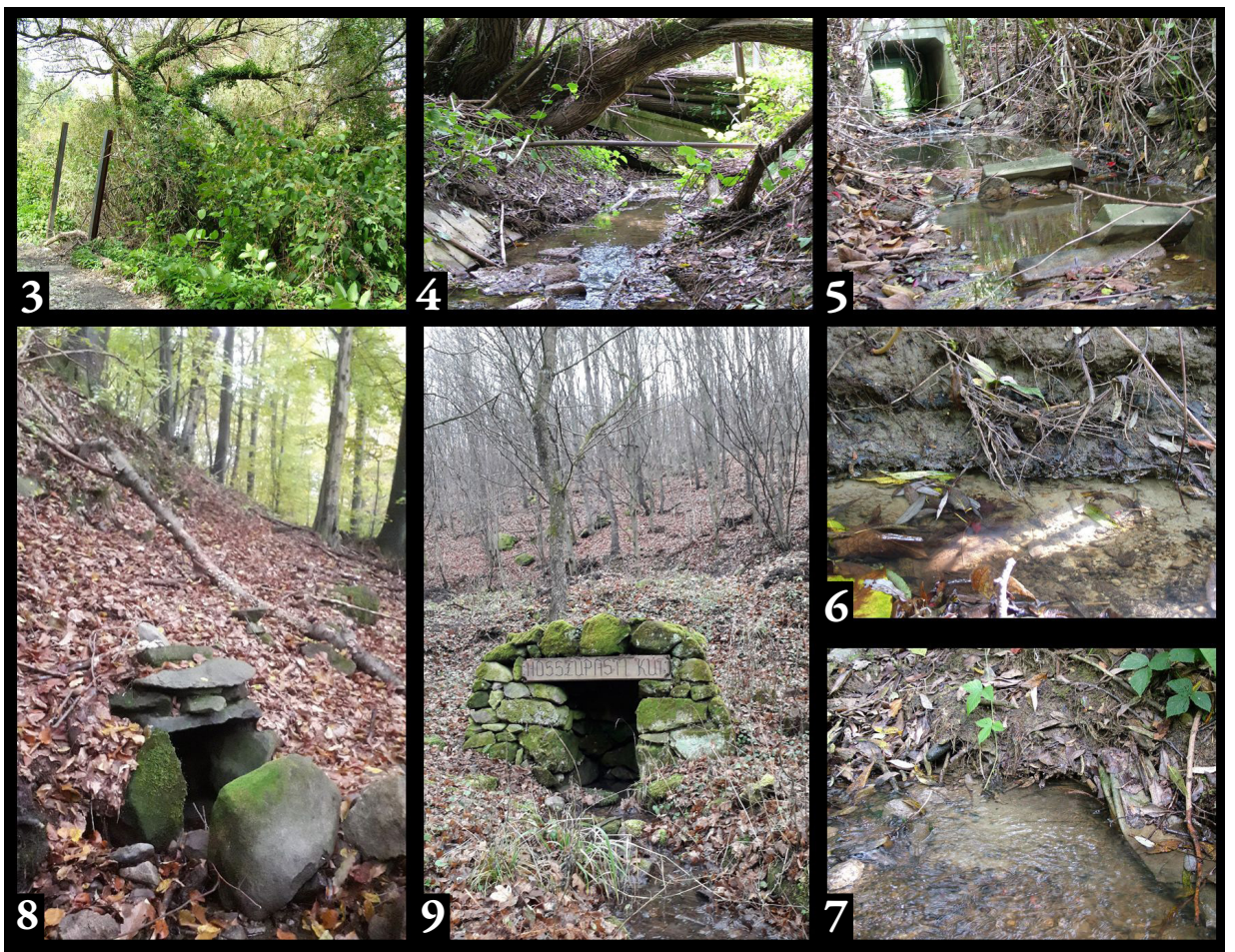

Figures 3-9. Stygobiont snail habitats in Hungary. 3-7 = Paladilhiopsis pallgergelyi sp. n., unnamed stream, Látó-hegy, Zákány, County Somogy; 8 = Alzoniella katagabriellae sp. n.; Vaskút, Diósjenő, County Nógrád; 9 = "dwarf form" of Bythinella austriaca (Frauenfeld, 1856), Hosszúpásti-kút, Bernecebaráti, County Pest 
The species Paladilhiopsis virei (Locard, 1903) from northern Italy has bulging whorls similar to those of the new species, but its aperture is comparatively larger and its spire is more slender.

While the teleoconch is ribbed in several Paladilhiopsis species, the microsculpture of this new species is extremely fine.

Family HYDROBIIDAE Stimpson, 1865

Genus Alzoniella Giusti \& Bodon, 1984

Type species: Alzoniella finalina Giusti \& Bodon, 1984; OD.

Alzoniella (Alzoniella) katagabriellae sp. n.

(Figs 8, 12, 14, 24)

Type material - Holotype: Hungary, Börzsöny Mts, Diósjenő, Vas-kút [well], $47^{\circ} 58.132^{\prime} \mathrm{N}, 19^{\circ} 00.092^{\prime} \mathrm{E}$, andesite bedrock, leg. A. Varga 03.10.2020, HNHM 97436. Paratypes ( $n=5)$ : one shell, same data as for holotype, HNHM 97437; two shells, same data as for holotype, coll. VA; two shells, same data as for holotype, leg. A. Varga, 24.10.2020, JG.

Holotype measurements - Shell height: $1.4 \mathrm{~mm}$; shell width: $0.77 \mathrm{~mm}$; aperture height: $0.58 \mathrm{~mm}$; aperture width: $0.46 \mathrm{~mm}$.

Diagnosis - An Alzoniella species with cylindrical shell, bulging whorls and high spire-aperture ratio.

Description - Shell minute, elongated, cylindrical, with pointed apex; whorls 4, bulging, suture deep (Figs 12, 14). Teleoconch sculpture with fine growth lines and very faint spiral striation (Fig. 24) (sculpture of Bythinella austriaca is similar, but stronger, Figs 23, 25). Spire 1.5 times as high as aperture; aperture small, oblique, higher than penultimate whorl from apertural view; peristome slightly expanded; umbilicus oblique, slit-like. Operculum and soft anatomy unknown.

Distribution - This new species is known only from the type locality.

Etymology - I name this new species after my daughters, Katalin Varga and Gabriella Varga.

Remarks on identification - As characteristic for the genus, its shell is small, whitish-translucent, conical or conical-cylindrical, with 3-4 bulging whorls and blunt apex. Aperture simple, umbilicus slightly open, slit-like.

The shell of Alzoniella (Alzoniella) hartwigschuetti (P. L. Reischütz, 1983) is dominated by the last two whorls (REISCHÜTZ 1983), robust, but A. katagabriellae sp. $\mathrm{n}$. is more slender. The species $A$. (Alzoniella) slovenica (Ložek \& Brtek, 1964) is also similar to the new species, but it is more robust, cylindrical, has deeper suture and more bulging whorls, and possesses a comparatively larger aperture (BERAN \& HORSÁ K 2001; SZA ROWSKA et al. 2011). 


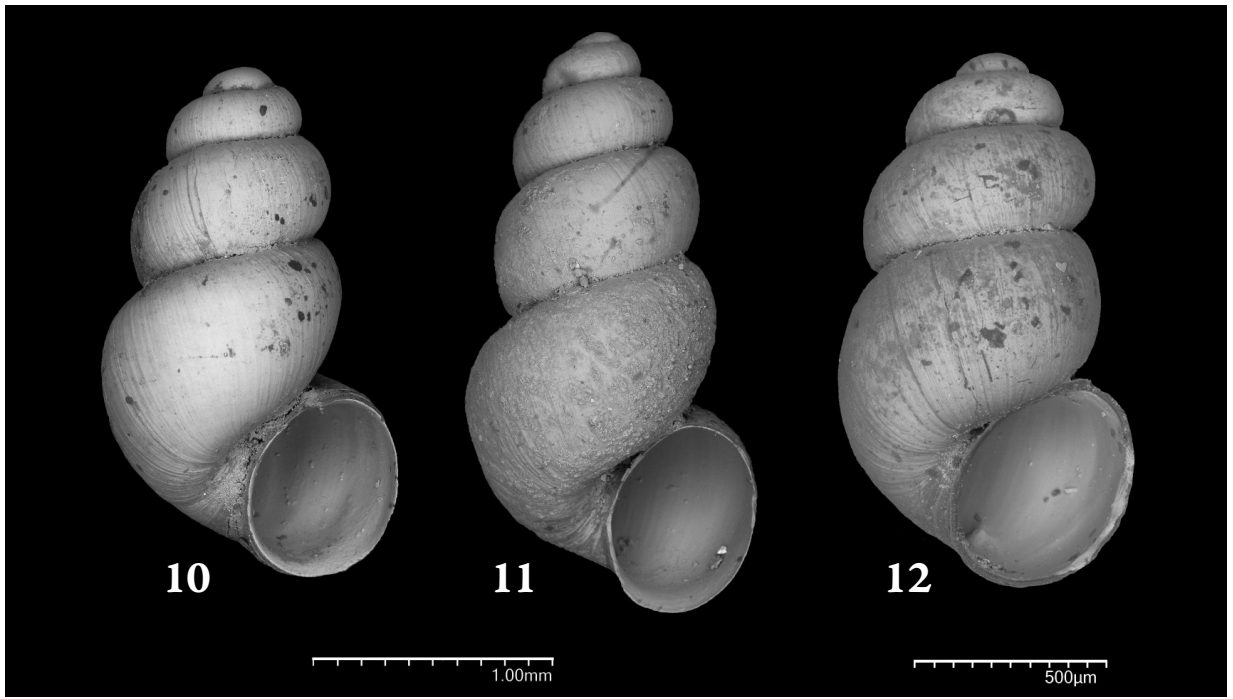

Figures 10-12. New stygobiont snail species type material. 10 = Paladilhiopsis pallgergelyi sp. n. holotype, HNHM-MOL-100000; 11 = ditto, paratype, HNHM 105276; 12 = Alzoniella katagabriellae sp. n. holotype. HNHM 97436

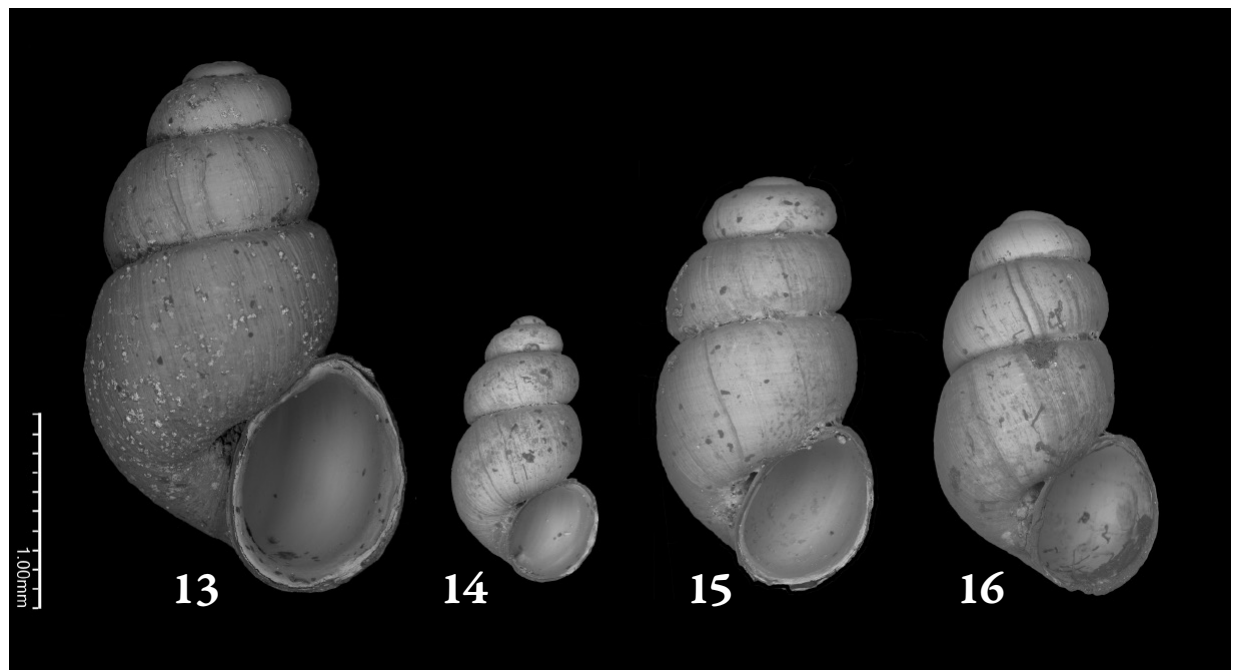

Figures 13-16. Hyrobiidae shells from the Börzsöny Mountains (County Nógrád, Hungary). 13 = Bythinella austriaca (Frauenfeld, 1856), Bernecebaráti, Hosszúpásti-kút; 14 = Alzoniella katagabriellae sp. n. holotype, Diósjenő, Vas-kút; 15-16 = Bythinella austriaca (Frauenfeld, 1856) “dwarf form", Bernecebaráti, Hosszúpásti-kút 


\section{Bythinella austriaca (Frauenfeld, 1856) "dwarf form"}

(Figs 9, 15, 16)

From the mud of a spring in the northern Börzsöny Mts, I collected empty shells reminiscent of unusually small Bythinella austriaca (Bernecebaráti, Hosszúvölgy [valley], Hosszúpásti-kút [well], 48 ${ }^{\circ} 01.041^{\prime} \mathrm{N}, 18^{\circ} 56.278^{\prime} \mathrm{E}, 29.10 .2020$ and 07.11.2020).

Most probably the water that usually flows out of the fountain could have drifted the shells out. The snail Bythinella austriaca is a common species of springs in the Börzsöny Mts, and the shell surface of the shells is almost always coated with a manganese layer. Such layer was absent on the shell surface of "dwarf" shells collected at the Hosszúpásti-kút. In contrast, those shells are translucent or opaque, without any external layer.

I found most shells in the mud of the spring's inner space, indicating that these were stygobiont animals. I also examined the flotsam and mud material collected after the outfall, which only contained Bythinella austriaca shells of normal size.

The genus Bythinella inhabits mostly springs and upper stream sections, and thus, may give birth to endemic species (FALNIOWSKI et al. 2012, GlöER 2013, OsikowsKi et al. 2015).

Thus, the "dwarf form" of Bythinella austriaca may also represent an ecological or biological species, which would await further examinations.

\section{DISCUSSION}

Stygobiont snails are found less frequently in the soil layers of the Dráva valley and the rock crevices of the volcanic bedrock-dominated Börzsöny Mts compared to karstic areas. Therefore, it is probable that the number of populations, and the number of individuals within populations are also smaller. Thus, besides systematic search of suitable habitat, numerous visits are suggested to increase chance of success. The stygobiont gastropod species in Hungary live in a great geographical distance between one another, which suggests that the subterranean water bodies they are associated to, are also isolated, and this would enhance birth of endemic species. The river Dráva fluctuates ca. $1 \mathrm{~m}$ daily, which results in a fluctuation of the groundwater as well. This "pumping" movement of the groundwater might have helped to flush the shells of Paladilhiopsis pallgergelyi sp. n. to the surface. The stream of the type locality (Figs 6-7) revealed a gravel/ sand layer at the border of the Pleistocene and Holocene deposits. The shells are probably originated from there, because I have not found any shells elsewhere in the stream bed. 


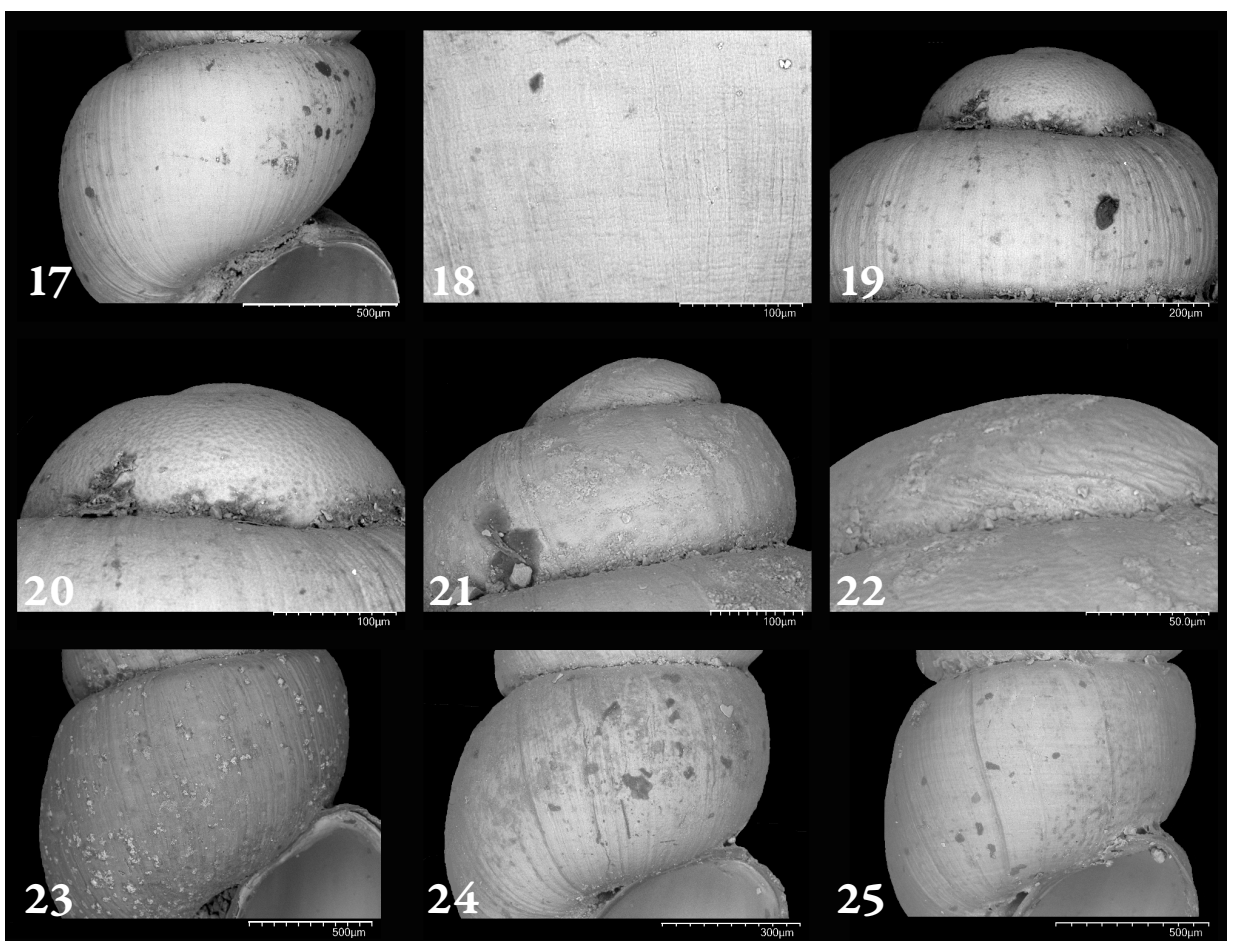

Figures 17-25. Sculpture of shells. 17-20 = Paladilhiopsis pallgergelyi sp. n. holotype; 21-22 = ditto, paratype; 23 = Bythinella austriaca (Frauenfeld, 1856); $24=$ Alzoniella katagabriellae sp. $\mathrm{n}$. holotype; $\mathbf{2 5}=$ B. austriaca "dwarf form"

I examined several springs of the Börzsöny Mts, but did not find shells of Alzoniella katagabriellae sp. n. elsewhere. The shells of the latter species have been only found in the mud of the inner spring bay, which indicates that this is a stygobiont species occurring only in underground waters. Hungary is situated at the edge of the geographical range of the genus Alzoniella (Slovakia, Austria, northern Italy, southern France, northern part of the Iberian Peninsula, Balearic Islands (ARCONDA et al. 2007). The species $A$. katagabriellae sp. n. is found between the type localities of $A$. slovenica and $A$. hartwigschuetti.

Acknowledgements - I am grateful to Barna Páll-Gergely (Plant Protection Institute, Centre for Agricultural Research, Budapest) for his help in translating the text and taking SEM images, to Jozef Grego (Banská Bystrica) for his advices and to Zoltán Fehér (WWF-Hungary, Budapest) for providing literature. 


\section{REFERENCES}

Angyal D., Balázs G., Krízsik V., Herczeg G.\& Fehér Z. 2018: Molecular and morphological divergence in a stygobiont gastropod lineage (Truncatelloidea, Moitessieriidae, Paladilhiopsis) within an isolated karstic area in the Mecsek Mountains (Hungary). - Journal of Zoological Systematics and Evolutionary Research 56(4), 493-504. https://doi.org/10.1111/jzs.12220

Arconada B., Rolan E. \& Boeters H. D. 2007: A revision of the genus Alzoniella Giusti \& Bodon, 1984 (Gastropoda, Caenogastropoda, Hydrobiidae) on the Iberian Peninsula and its implications for the systematics of the European hydrobiid fauna. - Basteria 71: 113-156.

BerAn L. \& Horsák M. 2001: Taxonomic revision of the genus Alzoniella (Mollusca: Gastropoda) in the Czech and Slovakia. - Biologia 56(2): 141-148.

CindRIĆ K. 2015: Špiljski puževi (Mollusca, Gastropoda) u Hrvatskoj subterranean snails (Mollusca, Gastropoda) of Croatia - Sveučilište U Zagrebu Prirodoslovno - Matematički Fakultet Biološki Odsjek, pp. 23. - https://urn.nsk.hr/urn:nbn:hr:217:210995 (Accessed: 2021-05-26)

CINDRIĆ K. \& SLAPNIK R. 2019: Two new subterranean freshwater gastropod species. (Gastropoda: Truncatelloidea) from the Rudnica VI cave in Croatia. - Natura Croatica 28(1): 45-50.

Clessin S. 1882: Eine österreichische Paladilhia. - Malakozoologische Blätter 5: 130-131. + Taf.2.

ERöss Z. \& Petró E. 2008: A new species of the valvatiform hydrobiid genus Hauffenia from Hungary (Mollusca: Caenogastropoda: Hydrobiidae). - Acta Zoologica Scientiarum Hungaricae 54(2): 159-167.

FALNIOWSKI A. 1989: A critical review of some characters widely used in the systematics of higher taxa of freshwater prosobranchs (Gastropoda: Prosobranchia), and a proposal of some new, ultrastructural ones. - Folia Malacologica 3: 73-94.

https://doi.org/10.12657/folmal.003.005

FALNiowski A. 1990: Anatomical characters and SEM structure of radula and shell in the species-level taxonomy of freshwater prosobranchs (Mollusca: Gastropoda: Prosobranchia): a comparative usefulness study. - Folia Malacologica 4: 53-142.

https://doi.org/10.12657/folmal.004.005

FAlniowski A. 2018: Species Distinction and Speciation in Hydrobioid Gastropods (Mollusca: Caenogastropoda: Truncatelloidea) - Archives of Zoological Studies 1: 1-6.

https://doi.org/10.24966/AZS-7779/100003

Falniowski A., Szarowska M., Glöer P., Pešić V., Georgiev D., Horsak M. \&, Sirbu, I. 2012: Radiation in Bythinella (Mollusca: Gastropoda: Rissooidea) in the Balkans. - Folia Malacologica 20: 1-9. https://doi.org/10.2478/v10125-012-0006-2

Fehér Z., Majoros G. \& VARga A. 2006: A scoring method for the assessment of rarity and conservation value of the Hungarian freshwater molluscs. - Heldia 6(3/4): 101-104.

Giusti F. \& Bodon M. 1984: Notulae Malacologicae, XXXI. Nuove Hydrobiidae dell'Italia nord-occidentale (Gastropoda: Prosobranchia). - Archiv für Molluskenkunde 114: 157-181. 
GLÖER P. 2013: New Bythinella species from Northern Romania. - Folia Malacologica 21(2): 55-66. https://doi.org/10.12657/folmal.021.006

Glöer P. \& GREgo J. 2015: New subterranean freshwater Molluscs from Bosnia \& Hercegovina (Mollusca: Hydrobiidae). - Ecologia Montenegrina 2(4): 307-314. https://doi.org/10.37828/em.2015.2.37

Grego J., Glöer P., ERőss Z. P. \& Fehér Z. 2017: Six new subterranean freshwater gastropod species from northern Albania and some new records from Albania and Kosovo (Mollusca, Gastropoda, Moitessieriidae and Hydrobiidae). - Subterranean Biology 23: 85-107. https://doi.org/10.3897/subtbiol.23.14930

Grego J., Glöer P., Falniowski A., Hofman S. \& Osikowski A. 2019: New subterranean freshwater gastropod species from Montenegro (Mollusca, Gastropoda, Moitessieriidae, and Hydrobiidae) - Ecologica Montenegrina 20: 71-90. https://doi.org/10.37828/em.2019.20.6

Hershler R. \& Ponder W. F. 1998: A review of morphological characters of hydrobioid snails. - Smithsonian Contributions to Zoology 600: 1-55. https://doi.org/10.5479/si.00810282.600

Hofman S., Rysiewska A., Osikowski A., Grego J., Sket B., Prevorčnik S., Zagmajster M. \& Falniowski A. 2018: Phylogenetic relationships of the Balkan Moitessieriidae (Caenogastropoda: Truncatelloidea). - Zootaxa 4486(3): 311-339. https://doi.org/10.11646/zootaxa.4486.3.5

Kerney M. P. \& Cameron R. A. D. 1979: A Field Guide to the Land Snails of Britain and North-West Europe. - Collins, London, 299 pp.

KusCer L. 1933: Prispevek k poznavanju podzemskih gastropodov Dalmacije in Hercegovine. Prirodoslovna Istrazivanja Kraljevine Jugoslavije 18: 59-67, Tab. 1.

Majoros G. 2010: A Szigetköz puhatestüi. - In: Gubányi A. \& MÉszÁros F. (szerk.): A Szigetközállattani értékei. - Magyar Természettudományi Múzeum, Budapest, p. 13-34.

MolluscaBAse eds. (2021). MolluscaBase. Paladilhiopsis Pavlovic, 1913. https://www.molluscabase.org/aphia.php?p=taxdetails\&id=723844 (Accessed: 2021-05-11).

Osikowski A., Georgiev D., Hofman S. \& Falniowski A. 2015: Does the genetic structure of spring snail Bythinella (Caenogastropoda, Truncatelloidea) in Bulgaria reflect geological history? - ZooKeys 518: 67-86. https://doi.org/10.3897/zookeys.518.10035

Pintér L. 1968a: Zur Kenntnis der Hydrobiiden das Mecsek-Gebirges (Ungarn) (Gastropoda: Prosobranchia). - Acta Zoologica Academiae Scientiarium Hungaricae 14(3-4): 441-445.

Pintér L. 1968b: Paladilhia oshanovae sp. n. (Gastropoda, Prosobranchia). - Malakologische Abhandlungen 2: 157-158.

RADOM AN P. 1983: Hydrobioidea, a superfamily of Prosobranchia (Gastropoda), I. Systematics. Monographs of the Serbian Academy of Sciences and Arts 547, Sciences 57:1-256.

ReIschütZ P. 1983: Beiträge zur Molluskenfauna Niederosterreichs, 4. Neue Taxa niederösterreichischer Hydrobioidea (Gastropoda). - Malakologische Abhandlungen 8: $149-153$.

Reischütz A. \& Reischütz P. L. 2008: Neue Hydrobiiden (Gastropoda, Prosobranchia, Hydrobiidae) aus dem Becken des Skutari-Sees (Montenegro/Albanien). - Basteria 72: 143-145. 
Rotarides M. 1943: Eine neue Paladilhiopsis-Art (Gastr. Prosobr.) aus einer siebenbürgischen Höhle, nebst einer Bestimmungstabelle der ungarischen Paladilhiopsis-Arten. - Fragmenta Faunistica Hungarica 6(1): 25-29.

SснÜтT H. 1970: Neue Formen höhlenbewohnender Hydrobiiden des Balkan und ihre Beziehungen zu Paladilhiopsis Pavlovic 1913. - Archiv für Molluskenkunde 100(1/3): 1-15.

SLAPNIK R. 1995: Razširjenost podrodu Bythiospeum (Paladilhiopsis) Pavlović 1913 (Gastropoda, Prosobranchia, Hydrobiidae) $\mathrm{v}$ osamelem krasu vzhodne Slovenije = Distribution of the subgenus Bythiospeum (Paladilhiopsis) Pavlović 1913 (Gastropoda, Prosobranchia, Hydrobiidae) in isolated karst of eastern Slovenia. - Razprave Sazu [Academia Scientiarum et Artium Slovenica], Razred za Naravoslovne Vede [Classis 4] 36: 59-89.

Soós L. 1927: Adatok a magyarországi barlangok Mollusca-faunájának ismeretéhez. - Állattani Közlemények 24: 163-180.

Szarowska M. 2006: Molecular Phylogeny, Systematics and Morphological Character Evolution in the Balkan Rissoidea (Caenogastropoda). - Folia Malacologica 14(3): 99-168. https://doi.org/10.12657/folmal.014.014

Szarowska M., Falniowski A. \& Šteffek J. 2011: Phylogenetic relationships of Alzoniella slovenica (Ložek et Brtek, 1964) (Caenogastropoda: Hydrobiidae) - Folia Malacologica 19(2): 87-95.

https://doi.org/10.2478/v10125-011-0009-4

Wagner A. J. 1914: Höhlenschnecken aus Süddalmatien und der Hercegovina. Sitzungsberichte der kaiserlichen Akademie der Wissenschaften in Wien, mathematischnaturwissenschaftlichen Klasse, Abteilung I. 123(1): 33-48.

Wagner A. J. 1928: Studja nad fauną mięczaków Półwyspu Bałkańskiego, w szczególności Bułgarji i Tracji, wraz z opracowaniem monograficznem poszczególnych grup. [Studien zur Molluskenfauna der Balkanhalbinsel mit besonderer Brücksichtigung Bulgariens und Thraziens, näbst monographischer Bearbeitung einzelner Gruppen.] - Prace zoologiczne polskiego panstwowego muzeum przyrodniczego 6: 295-298.

Wagner H. 1931: Vorläufige Mitteilung über die Molluskenfauna der Grotte von Mánfa in Südungarn. - Zoologischer Anzeiger 95: 292. 


\title{
Két új szubterrán édesvízi Gastropoda faj Magyarországról (Mollusca: Gastropoda: Truncatelloidea)
}

\author{
VARGA ANDRÁS \\ Magyar Természettudományi Múzeum Mátra Múzeuma, 3200 Gyöngyös, Kossuth Lajos utca 40. \\ E-mail:avarga8946@gmail.com
}

Összefoglalás - A szerző 1998 és 2020 között a Duna-Dráva Nemzeti Park és a Duna-Ipoly Nemzeti Park területén végzett kutatásai során két, tudományra új szubterrán csigafajt fedezett fel. Az első faj a Paladilhiopsis pallgergelyi sp. n., Zákány település közelében a Dráva-völgyében él, mintegy száz méterre a horvát-magyar határtól. A második faj az Alzoniella katagabriellae sp. n., amelyet Diósjenő községhatárában a Börzsöny-hegység egyik forrásában talált meg. A földalatti életmódú fajok különleges és ritka értékei a hazai faunának. A Dráva kavics-hordalékkúpjának talajfelszín alatti vizeiben elszigetelten élő $P$. pallgergelyi sp. n. és a Börzsöny-hegység andezit kőzetrepedéseiben, kőzettörmelékének vízereiben előforduló $A$. katagabriellae sp. n. egy-egy újabb bennszülött faja a hazai Mollusca faunának. A Paladilhiopsis nemzetség Magyarországon a Mecsek-hegységben fordul elő. Az Alzoniella nemzetség új előfordulási adat Magyarország területéről, fajai legközelebb a szomszédos Szlovákia és Ausztria karsztos területein élnek. A szerző még a Bythinella austriaca (Frauenfeld, 1856) érdekes törpe alakját jelzi a Börzsönyhegységből.

Kulcsszavak - Gastropoda, Moitessieriidae, Paladilhiopsis, Hydrobiidae, Alzoniella, Magyarország

\section{ÁBRAALÁÍRÁSOK}

1. ábra: A Paladilhiopsis pallgergelyi sp. n. típuslelőhelyének földrajzi elhelyezkedése a Drávavölgyben (Somogy megye, Magyarország)

2. ábra: Magyarországi édesvízi csigalelőhelyek. Az Alzoniella katagabriellae sp. n. típusanyagának (piros kör) (Nógrád megye) és a Bythinella austriaca (Frauenfled, 1856) „törpe forma” lelőhelyének (fekete kör) (Pest megye) földrajzi elhelyezkedése

3-9. ábra: Édesvízi csigafajok élőhelyei Magyarországon. 3-7 = Paladilhiopsis pallgergelyi sp. n.: Somogy megye, Zákány, Látó-hegy, névtelen vízfolyás; 8 = Alzoniella katagabriellae sp. n.: Nógrád megye, Diósjenő, Vas-kút; 9 = Bythinella austriaca (Frauenfeld, 1856) „törpe forma”: Pest megye, Bernecebaráti, Hosszúpásti-kút 
10-12. ábra: Édesvízi csigafajok típusanyagai. 10 = Paladilhiopsis pallgergelyi sp. $\mathrm{n}$. holotípus, HNHM-MOL-100000; 11 = u. a., paratípus, HNHM 105276; 12 = Alzoniella katagabriellae sp. n. holotípus HNHM 97436

13-16. ábra: Börzsöny-hegységi Hyrobiidae fajok házai. 13 = Bythinella austriaca (Frauenfeld, 1856), Bernecebaráti, Hosszúpásti-kút; 14 = Alzoniella katagabriellae sp. n. holotípus, Diósjenő, Vas-kút; 15-16 = Bythinella austriaca (Frauenfeld, 1856) „törpe forma”, Bernecebaráti, Hosszúpásti-kút

17-25. ábra: Hyrobiidae fajok házainak skulpturája. 17-20 = Paladilhiopsis pallgergelyi sp. n. holotípus; 21-22 = u. a., paratípus; 23 = Bythinella austriaca (Frauenfeld, 1856); $24=$ Alzoniella katagabriellae sp. n. holotípus; 25 = Bythinella austriaca (Frauenfeld, 1856) "törpe forma” 